\title{
AN ANALYSIS OF THE USE OF COUNTERPART FUNDS \\ IN MOZAMBIQUE
}

\section{Barry Riley}

\section{CONTEXT OF THE STUDY}

There is growing consensus (Bruton and Hill 1991, Maxwell and Owens 1991, Riley and McClelland 1990, World Bank 1991) on how counterpart funds (CF) can be managed more effectively in recipient countries. However, in practice, there are many procedural and managerial difficulties to overcome. This case study describes efforts to improve CF generation, collection, management, accounting and reporting in Mozambique, a country where CF comprise a large share of government revenue and where government and donors both agree that improved CF management is urgently needed.

Such a study is useful from several perspectives. First, since $C F$ are such a significant source of government revenues, the efficiency with which donor commodity and financial assistance is converted into budget resources is important from a fiscal planning perspective. Second, the extent to which both public and private enterprises and agencies seek ways to defer or avoid payment of $\mathrm{CF}$ provides insight into the financial health of the enterprise sector. Third, the relationship between deferred payment of counterpart funds by the beneficiaries and overall credit creation in the economy requires further exploration, particularly when the Government is operating within credit and expenditure ceilings which have been negotiated with the IMF and the World Bank. Fourth, the appearance of quite different perceptions between the donors and the government on what constitutes adequate reporting and accounting and on the definitions of eligible uses have proved to be areas of significant friction between donors and government.

Counterpart funds in Mozambique, as elsewhere, are local currencies (meticais) generated from the sale to private and public enterprises of imported goods, or the foreign exchange to purchase such goods, provided as balance of payments or commodity import support by bilateral and multilateral donors. Counterpart is generated from certain types of food aid, non-food commodity aid, foreign exchange support and some forms of project aid. Though each of these forms exhibits unique characteristics, they all, in one way or another, make foreign exchange available to the Government of Mozambique or directly to private importers ('beneficiaries') under grant or concessional loan terms which is used to purchase foreign-source goods and/or services. The beneficiary (whether in the private or public sector) is expected to provide the metical ${ }^{1}$ equivalent of the foreign exchange value of the commodities or services into one of three Ministry of Finance accounts maintained in either the Banco de Mozambique or the Banco Popular de Desenvolvimento. ${ }^{2}$ In theory, a deposit is normally to be made at the time the import licence is granted and the remaining balance paid at the time the goods arrive. These CF deposits are then used in one (or more) of four ways:

i moved from the Ministry of Finance accounts into the treasury for disbursement within the budget;

ii used to draw down outstanding parastal debt;

iii sterilized as a monetary offset against credit created by the banking system;

iv transferred back to the donor to cover some portion of that donor's local expenses.

\section{THE MAGNITUDE AND MANAGEMENT OF COUNTERPART FUNDS}

Donors provide considerable foreign exchange or commodity assistance on grant or concessional loan terms. In 1990, the estimated CIF value of imported goods was $\$ 864$ million. ${ }^{3}$ In that same year, all donor assistance to Mozambique (excluding aid in support of the 'emergencia') was estimated to be approximately $\$ 622$ million. The total potential counterpart collection is estimated to be approximately 60 per cent of this amount, ${ }^{4}$ i.e., in the range of $\$ 365-390$ million. Actual

Gowdie, 1991 for an interesting discussion of the accounting implications of these three accounts.)

${ }^{2}$ Account No. 1 at BDM receives funds generated under the IDA Rehabilitation Loans and related co-financing. Funds in this account are normally frozen, although some portion are used to assume bad enterprise debt by the government. Account No. 2 at BDM receives most other counterpart fund deposits. These funds are directed into the budget or back to donors, either through the budget or 'offbudget'. Funds generated by the World Bank Small and Medium Enterprise Project, the Household Energy Project and IFAD projects are deposited in the BPD account. These funds are used for on-lending for certain types of project activities. (See Annex $I$ in
${ }^{3}$ The data used in this paper are preliminary and subject to correction and adjustment. They should be treated primarily as order-ofmagnitude indicators.

${ }^{4}$ The remaining 40 per cent is the estimate of non-emergency donor support for government projects which generate no counterpart funds. Ranges of values rather than absolute amounts are used because of the preliminary nature of the figures. 
collection of CF in 1990 was in the range of $\$ 190$ 225 million and total utilized in the budget was between $\$ 150-180$ million. ${ }^{5}$

Counterpart funds actually collected represent an important source of revenue for the Mozambican Government and also a significant share of the money stock and GDP. In 1990, an estimated 30 per cent of aggregate government expenditures were financed by CF which also represented around 40 per cent of the money stock and 15 per cent of GDP. ${ }^{6}$ But CF thus expended or accumulated in government accounts represented only about 50 per cent of the local currency value of total potential counterpart funds that could have been generated from external sources.

From an accounting perspective, the Ministry of Finance is able to account for approximately $75-80$ per cent of the total potential counterpart (\$285$\$ 320$ million). The 'unaccounted for' balance (for which estimates range from $\$ 50$ to $\$ 100$ million) may, in fact, have been generated (i.e. paid by the beneficiaries into the Ministry of Finance accounts set up to receive these payments) but not yet correctly reported, or it may have been uncollected (unpaid by the beneficiary). There is some evidence suggesting that a significant portion of the unaccounted for balance can be ascribed to food aid arrivals for which actual payment of counterpart in 1990 constituted only about 25 per cent of the computed local currency value that should have been paid. What is perhaps of greater interest, only 2 per cent of this uncollected amount was covered by promissory notes to denote officiallysanctioned deferred payment (and against which the government issued letras de tesouro). The remainder, equalling nearly three-quarters of the local currency value of programme food aid, appears not to have been paid by the recipients, nor were deferred payments negotiated. Since this food is sold into the market by parastatals, wholesalers and distributors, non-payment constitutes an implicit, possibly unintended, fiscal transfer or grant and is, in effect, a (presumably unwanted) non-transparent subsidy to these importers.

It is simplistic to assume that all counterpart that could be generated will be generated. It is thus informative to look at the nature and magnitude of uncollected counterpart as indicative of the pace with which counterpart is likely to be made available for future budget expenditures. This may also suggest something about the health of the enterprise sector.

\footnotetext{
'The difference between collection and expenditure in any given 12 month period being net accumulation in the government's counterpart accounts. In 1990 this was approximately $\$ 40$ million.

${ }^{6}$ Again, these estimates are approximations only:

${ }^{7}$ Or the Banco de Mozambique acting as the agent of the Ministry of Finance.

${ }^{8}$ The distinction between these two documents is not relevant here. Both officially sanction deferred payments by public or private
}

In theory, the importing enterprise makes a metical deposit of a portion of the value of the commodities at the time the import licence is granted and pays the remainder when the goods are collected from the port. Payment is made either from the enterprise's own resources or from credit obtained from the banking sector. Often, however, the importing entity seeks to defer payment of the counterpart. This is done by requesting the Ministry of Finance ${ }^{6}$ to issue a Letra de Tesouro or a Subsidiary Agreement ${ }^{8}$ against the enterprise's promissory note. This is a common practice in Mozambique, caused in part by the weak financial and cash flow position of many enterprises and in part because requests for deferred payment have been so readily granted by the authorities. In 1990, the total of these two forms of deferred CF payment was estimated to be approximately $\$ 80$ million - equalling about half the value of counterpart funds actually used in the budget.

The timing of the deferred payments is negotiated on the basis of the pace with which the importer is expected to be able to sell the goods to wholesalers, retailers or end users or to generate revenue. Thus, counterpart payments for raw materials and capital goods will be deferred over a longer term than payments for finished goods or consumer goods for which sale and generation of cash flow will be more rapid. The composition of imported commodities financed by the donors thus has an impact on the pace with which counterpart funds are paid into government accounts.

In some cases, e.g., railroad equipment and spares where the railroad continues to operate at a loss, no net additional revenues are generated as a result of the importation of donor-financed equipment, and no counterpart can be paid. For situations such as this, full 'exemptions' from counterpart payment are sometimes granted (totalling approximately $\$ 7$ million in 1990). The number, value and timing of such exemptions obviously has a significant effect on counterpart collections and revenue availability.

Counterpart payments are made by the importers into one of two Ministry of Finance accounts in the Central Bank (BDM) or into an account in the BPD. From one of the BDM accounts ('MB-10') and the BPD account, funds are then periodically transferred into the Treasury for use in the budget. ${ }^{9}$ Balances in the other BDM account ('No. 1') ${ }^{10}$ are frozen and used to

enterprises of the full local currency value of commodities whose foreign exchange costs have been covered or subsidised by one or more donors.

${ }^{9}$ As noted earlier, counterpart flows in any time period include counterpart expended by government plus net changes in the counterpart accounts' balances.

10 This account is comprised of counterpart generations from World Bank Rehabilitation Credits - including co-financing. 
sanction an equal amount of externally-financed credit to the non-government sector. A certain portion of MB-10 balances and, occasionally, of Acct. No. 1 balances are used to 'buy down' the debt of public sector parastatals.

The Mozambican Government is currently operating under the provisions of the Economic and Social Recovery Programme (ESRP) wherein government expenditures are constrained by a 'reduction clause'. This requires that any counterpart inflows used in the budget above a predetermined fixed level automatically lead to compensating reductions of like amount in net credit made available to the government by the banking system. This is an important point: to the extent that counterpart collections increase for any reason, the result will almost certainly be to decrease government utilization of credit from the banking system by a like amount and to increase bank credit available to the non-government sector. Since the government is already planning to make net repayments to the banking system over the next two years, any increase in effective generation of counterpart will have the effect of redistributing credit expansion from the government to the non-government sector.

Looking at counterpart from another perspective, there is no mechanism in place which automatically compensates the government when actual collections of counterpart fall short of projections, since government borrowing from the banking system is constrained by credit ceilings which are observed. The government normally operates at, or close to, the ceiling. In the case of Mozambique, projections of counterpart-derived revenues over the next two years anticipate a healthy increase. Should enterprise health not prove as robust as anticipated and growth be slower, the ability of the enterprise sector to generate necessary levels of counterpart will be impaired and government expenditures would be cut back, of necessity.

There are, in any regard, concerns about the financial health of the enterprise sector and what this implies about reliance on counterpart flows to support either higher levels of government expenditures or additional credit availability. As noted in the discussion of deferred payment of counterpart, one reason for the large number of importers seeking to delay payment is that the financial health of many of these enterprises is not robust. Inventories are believed to have been building up, or there exist impediments to manufacturing and/or marketing which inhibit generation of cash flow. Under these circumstances, one can infer that many enterprises in both public and private sectors are experiencing, and will continue to experience, difficulty in generating local currency in sufficient quantity to purchase donor-provided commodities or foreign exchange. This implies that:

i projections of significantly increased flows of counterpart are probably optimistic;

ii present levels of commodity and foreign exchange assistance exceed the real absorptive capacity of the enterprise sector, and/or;

iii donors will have to provide more of these commodities on a grant or subsidised basis - a practice in which many, in one way or another, are already engaged.

\section{DONOR CONCERNS AND ISSUES}

The donor perspectives on this and other problems vary considerably. Some donors have not focused much attention on the counterpart implications of their programmes. Others have been concerned principally with uses or earmarking of counterpart funds in, or outside, the budget, while others have required that the government demonstrate that the local currency equivalent of the value of donor-financed imports has been placed in a special account within a fixed time, whether or not the imports in question have actually generated CF. Complicating the situation further, some donors designate individual enterprises as recipients of donor-financed imports in the absence of knowledge about the recipient's financial status. Nonetheless, the donor may still require that the government deposit the full counterpart value of the imports into a special account within a specified time period, typically 180 days after arrival of the goods. Obviously, if the importer cannot provide the counterpart, the government has to find its equivalent elsewhere." If, in addition, the donor requires that the counterpart (or counterpart equivalent) be expanded in accord with the donor's preferences or earmarked for donor-selected purposes, there can be an adverse impact on resources available for the budget or debt buy-downs.

All this is somewhat theoretical, however, because it is difficult in the extreme to determine what actually happens. There are approximately ten donors whose programmes generate significant amounts of counterpart funds in most years. Each donor has distinct requirements regarding how the commodities are to be valued in determining counterpart equivalency,

\footnotetext{
"At least one donor, explicitly recognizing the impact on counterpart generation and the potential for unintended subsidies when an importer is selected who is unwilling or unable to pay the value of the donor-provided commodities, is now requiring that an importer deposit a portion of the payment at the time the import licence is
}

obtained and pay the balance when the commodities arrive using either the importer's own resources or bank credit. No promissory notes or exemptions will be allowed. If the importer is unable to meet these requirements, the goods are to be auctioned to another importer able to make such payments. 
accounting practices to be used, types and timing of required reporting on counterpart accumulated under that donor's programmes, actual uses of the counterpart and auditing requirements.

The donors can be separated into two basic groups those who require reporting from the government on these aspects and those who do not. Until recently only three or four donors required reports on the disposition and management of their counterpart. Now, many donors are requesting timely reporting on:

\section{i the amount of their counterpart actually collected;}

ii the extent to which the various conditions they have attached to the use of their counterpart have been satisfied and;

iii the actual usage of their counterpart.

The government, until recently relatively lax in reporting, has increasingly been pressed by the donors to account for individual counterpart contributions. While, as noted above, the Ministry of Finance and the Central Bank are able to account, from a macro perspective, for most of the counterpart that theoretically is supposed to be generated in a given time period, the ability to track the status of counterpart funds from individual shipments, stemming from particular agreements between the government and a given donor for a specific year, is considerably less well developed - and quite burdensome. The Ministry of Finance has recently been attempting to develop a methodology for tracking the status of counterpart originating from particular agreements and shipments. This is intended, among other things, to provide data for preparing individualized reporting to each donor on the status of counterpart creation, accounting and uses of that donor's counterpart. As of November 1991 this tracking system was not yet operational.

In the November 1989 Consultative Group meeting in Paris, the donors and the government agreed to work towards establishing a common counterpart system in which the differing requirements on counterpart valuation, ${ }^{12}$ timing of deposits, government accounting and auditing procedures, counterpart uses, earmarking and reporting would be harmonized and, to the extent possible, unified in a common framework. This would enable the Mozambicans to perform against one set of guiding principles rather than eight or ten. In December 1990 a progress report provided to the Consultative Group (World Bank/USAID 1990) indicated that significant progress had been made including movement toward agreement on a system of common valuation, development of a draft prototype agreement to be used by all the donors, and development of a set of common policy objectives to guide donors and government on counterpart management and use. These objectives, expressed as a set of guiding principles, were:

i achievement of greater efficiency and simplicity through improved harmonization;

ii support for the principle of 'budgetary transparency', i.e., reduction and eventual elimination of off-budget, unaccounted uses of counterpart funds, and;

iii promotion of sound economic policies in the programming of counterpart funds.

During the past year minimal additional progress has been achieved by the donors and the government in harmonizing procedures or reporting and accounting requirements. There has been little use made thus far of the prototype agreement format. The valuation of commodities still differs significantly between the donors. ${ }^{13}$ In the meantime, many of the donors, who heretofore had not pressed the government for accurate and timely reporting on counterpart, began doing so. In the absence of agreement among the donors on a common reporting format, such reporting would have to be done using many different, often complex formats. In addition, reporting on 'uses' of counterpart funds generated from particular shipments of commodities would, as noted previously, cause major monitoring and accounting problems. Since payments by the importers related to specific shipments or under terms of specific agreements often are made late, or only in part, or sometimes not at all, it is difficult to track these particular payments through the accounting process, into the Treasury and then to specific line items in the budget. It is, at best, an attribution exercise, and, given the basic fungibility of these resources as they pass through one or more co-mingled accounts, an exercise in frustration. Nonetheless, several of the donors are increasingly insistent that the government provide them with reports on the specific final uses of 'their' counterpart funds.

Another problem has been the insistence by several donors that some portion of the counterpart funds generated by their commodity support programmes be deposited in accounts under their control to help cover

\footnotetext{
${ }^{12}$ In establishing the valuation of food aid, some donors have used the domestic Mozambican price for a given commodity to determine the amount of counterpart to be generated, some have used estimated CIF prices, one has used a percentage of $F O B$, some have used $F O B$ or FAS prices. There was, at the time of the CG meeting, agreement in principal that WFP or FAO would be asked to determine a reasonable border parity price for each food commodity based on
}

actual commercial rates and that all donors would agree to use this value in determining the valuation for a set number of months 6 or 12). This system has yet to be implemented.

${ }^{13}$ Thus complicating even further the already difficult art of projecting counterpart generations and the revenue to be derived by the government therefrom. 
some of their own in-country expenses. In some cases, these funds, which are in a sense 'granted back' to the donor, can be as high as 10 per cent of the total generations, do not necessarily pass through the budget process and are thus invisible to those trying to bring more order to the government's accounting systems, and do not necessarily relate to development priorities.

There is need for the government and the donors to resume the dialogue on counterpart issues leading to simplified and common procedures for valuation, a single reporting and accounting system acceptable to the donors, and one within the realistic performance capabilities of the government. In addition, the government needs to replace the present system of deferred counterpart payments with one where the importing beneficiaries pay as promptly for the donorsupplied foreign exchange and/or commodities as would be the case for normal commercial imports and where enterprises seeking credit to finance these imports would go to the commercial banking sector not to the Ministry of Finance.

\section{CONCLUSIONS}

Counterpart funds are an important source of revenue to the government, but potential total flows are considerably larger than actual flows. This is due in part to the financial weakness of the enterprise sector both private and public - and in part due to weak enforcement of payment requirements. This is particularly the case for programme food aid, where non-payment rather than deferred payment is characteristic. There is considerable room for increased counterpart collection and increased revenue flows.

Under present operating policies, additional revenues would not result, necessarily, in increased on-budget expenditures. If the government were (as is usually the case) expending at or near the expenditure ceilings imposed within the framework of the ESRP, additional counterpart made available to the Ministry of Finance would be used to retire bad parastatal debt and to reduce the government's recourse to banking sector borrowing. This, in turn, would increase net credit availability to the private sector.

There are areas of actual and potential friction betwen the government and the donors, particularly in methods of accounting, reporting and on-budget (as well as donor pressures for off-budget) uses. There is room for compromise betwen donor demands for additional reporting and the government desire for harmonized, simplified reporting and accounting procedures. The dialogue process which has been stalled for more than a year needs to resume.

\section{REFERENCES}

Bruton, H. and Hill, C., 1991, 'The Development Impact of Counterpart Funds'. Report for the US Agency for International Development. Document No. PN-ABH-074.

Clément, J., 1989, The Macroeconomics of Counterpart Funds. International Monetary Fund

Gowdie, A. W., 1991, 'The macroeconomic importance of counterpart funds in Mozambique', unpublished monograph

Green, R. H., 1991, 'Macroeconomic aspects of commodity aid and counterpart funds in sub-Saharan Africa', Discussion Paper No 290, IDS, Sussex, June

Maxwell, S., with Owens, T., 1991, 'The developmental uses of counterpart funds', Discussion Paper No 289, IDS, Sussex, June

-and Owens, T., 'Commodity aid and counterpart funds in Africa, Discussion Paper No 291, IDS, Sussex, June
Owens, T., 1991, 'Counterpart funds: an annotated bibliography', Development Bibliography No 6, IDS, Sussex, November

Riley, B. and McClelland, D., 1990, 'Enhancing the effectiveness of counterpart funds in Mozambique'. Paper prepared for the meeting of the Consultative Group for Mozambique, Paris, December 1990

Roemer, M., 1988, 'The macroeconomics of counterpart funds', Discussion Paper No 262, Harvard Institute for International Development

US Agency for International Development, 1990, 'Toward an effective and efficient utilisation of counterpart funds in Mozambique', Paper prepared for the Meeting of the Consultative Group for Mozambique, Paris, December 1990

World Bank, 1991, SPA Working Group on Counterpart Funds Draft Guidelines on Counterpart Funds, Washington 